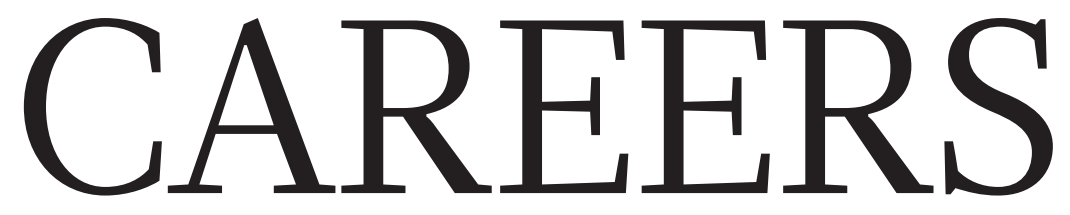

TURNING POINT After stints in Nobel labs, a structural biologist returns to India p.397

NATUREJOBS BLOG The postdoc series:

Setting up your own lab go.nature.com/gk213b
@NATUREJOBS Follow us on Twitter for the latest news and features

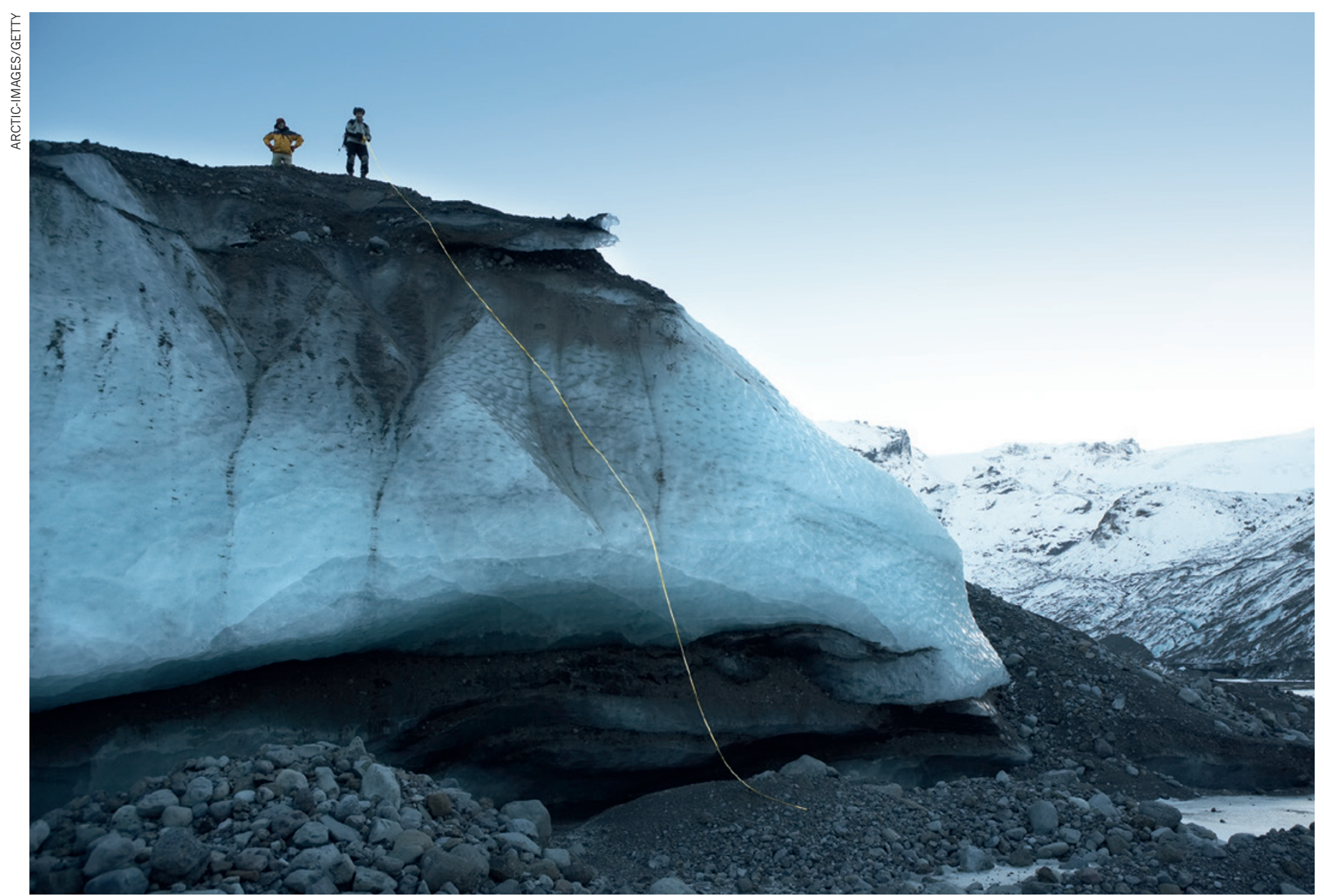

The Glaciological Society measures ice of glaciers each year for research now used to study global warming.

\title{
GLACIOLOGY
}

\section{Climatology on thin ice}

\section{Ice-core scientists struggle to adapt as the subject of their research melts away.}

\section{BY NEIL SAVAGE}

$\mathrm{W}$ hen Margit Schwikowski hiked up a glacier on the Svalbard islands in the Arctic Ocean a few years ago to collect ice samples for her climate research, she was gob-smacked. The Swiss analytical chemist had been to this site in 1997 to drill a core to test for trace gases and aerosols in her $\mathrm{lab}$ at the Paul Scherrer Institute in Villigen. But when she returned in 2009 for fresh samples, she could no longer reach the site: the warming glacier had cracked open and developed a yawning crevasse.

"You cannot go there," she says today. She has not tried to return since. It would be pointless, in any case - the crack had let in fresh snowfall and melt water, which then mixed with ice deeper in the glacier and confused any data that a scientist might try to extract.

Scientists who study the cryosphere places on Earth that are sheathed in ice - are finding their jobs more difficult as the ice melts and glaciers recede. The subject that they study, climate change, poses intellectual challenges to their science and physical challenges to the way they approach fieldwork. Ice-core researchers need to be aware of how changing conditions affect the quality of their data. They must be prepared to go to more extreme environments to get their samples, and to face the challenges of those environments, such as dangerous terrain and low levels of oxygen.

And, unusually within fields of scientific study, ice-core scientists must find ways to 
- preserve the object of their study for future researchers before it vanishes forever - by stepping up efforts to collect and store the ice.

\section{MEASURING THE MELT}

Disappearing ice can complicate not just sample collection, but also analysis. Qianggong Zhang, an environmental geochemist at the Chinese Academy of Sciences in Beijing, knows this all too well. In 2005, he and colleagues at the academy's Institute of Tibetan Plateau Research climbed a glacier in Tibet to extract an ice core. Back at their lab, they characterized the ice layer by layer, measuring the concentrations of trapped gases and gathering other chemical information. But then they discovered that the top layers of ice were missing, rendering their work useless.

Scientists date ice cores by counting their layers, which vary as the seasons change and leave distinctive stratification. If the ice core is intact, the top layer should be the mostrecent year; from there, researchers can tie what they learn to other information, such as records of temperature or precipitation. They can also look for signatures that serve as labels for specific years: atmospheric nuclear tests in the 1950s and 1960s, for instance, left a datable signature in glaciers worldwide, as did the 1986 Chernobyl meltdown in the then-Soviet Union.

Zhang's group had already done a lot of work before it noticed something amiss: none of its ice contained any trace of radioactive fallout. A core free of radiation indicated that the ice from those years had melted away - and Zhang's most recent layer of ice had to have come from a year earlier than 1950. But there was no good way to determine the top layer's age. "Our work on the other

"We have
to find new
methods to
dig out the
information in
the partially
melted ice."

parameters is probably just a waste of time," Zhang laments. So the team's measurements sit in his computer, waiting for researchers to develop different dating methods. They wait, too, for a way to analyse layers that are chemically tainted by more-recent water. "We have to find new methods to dig out the information in the partially melted ice," Zhang says.

Some of that information could come, for example, from studying stable isotopes of oxygen that remain in partially melted ice, and remnants of insoluble material such as black carbon might help researchers to count layers. Although these clues might not be enough for scientists to obtain year-to-year data from the ice, they could enable them to retrieve average measurements from 5- or 10-year periods. It could also be possible for researchers to sift through the sediments of glacial lakes to retrieve material that has been washed out by ice melt, and treat that material as a proxy for the ice. But in samples that lack the radioactive signature, it

CLIMB ANY MOUNTAIN Glaciology is an outdoors game

Young scientists who are considering a career in ice-core palaeoclimatology ought to have some experience with climbing, says Doug Hardy of the University of Massachusetts Amherst, if only to know whether or not they can handle it. He thinks that scientists who study ice cores need to see where those cores come from. "You can't really understand the physical processes and mechanisms by which palaeoclimate archives are created unless you really experience the environment in which it happens," he says. "Those who are making the interpretations need to be grounded in reality."

But high-altitude work can be challenging. "The air becomes too thin for helicopter operations. You have to carry everything up yourself," says Margit Schwikowski of the Paul Scherrer Institute

may never be possible to pinpoint specific years.

"Time no longer starts at the surface," says Lonnie Thompson, a palaeoclimatologist at the Byrd Polar Research Center at the Ohio State University in Columbus. He and his wife, Ellen Mosley-Thompson, have been collecting ice cores since the mid-1970s. He drilled an ice core from the Quelccaya ice cap in the Peruvian Andes in 1983, at which point no melting had occurred at altitudes above 5,000 metres. When he returned for another sample 20 years later, melting had altered the concentration of atmospheric isotopes in the top 40 metres of ice.

\section{FREEZING FOR THE FUTURE}

One way to get - and get to - a pure sample is to climb higher, where melting is not yet a problem. But that works only if there is actually somewhere to go. "In most cases, we can't go any higher. We can't get to a colder environment," says Douglas Hardy, a geoscientist at the University of Massachusetts Amherst.

Hardy places weather instruments on glaciers such as the one on Mount Kilimanjaro in Tanzania, which has shrunk by about 4 metres in the past 15 years. The instruments measure various meteorological conditions temperature, humidity, precipitation rates and the amount of sunlight that strikes the glacier — and will help scientists to examine how those conditions affect growth or shrinkage of the ice layers. If scientists do not take those measurements before the ice is gone, "all opportunities will be lost and we will never know what the glacier-ice history in Africa has been", Hardy says. Going higher on the few global sites that still exist, meanwhile, can be dangerous. "It's a risky business if you go to altitudes in this range of 6,000 metres or higher," Schwikowski says in Villigen, Switzerland. That can mean hauling up 6 tonnes of equipment, and then bringing back 4 tonnes of ice on top of that. Mountaineering scientists need time to acclimate to lower levels of oxygen, and must guard against altitude sickness. "You work more slowly and you walk more slowly and you climb more slowly and everything takes more time," Schwikowski warns.

Those who do not have the inclination or the ability to climb glaciers can still contribute by performing tests and computer modelling on the ice cores that others bring back. There are also other ways to conduct palaeoclimatology research that do not involve high altitudes, although they, too, pose physical challenges. There is work being done on Antarctic ice cores where elevations are lower, as well as on coral reefs and stalactites in caves. N.S.

(see 'Climb any mountain').

The ice-core community is discussing ways to save ice for the next generation of scientists, who will have more-advanced theories and measuring tools available to them. In February, Patrick Ginot, a palaeoclimatologist at the Institute of Research for Development (IRD) in Marseilles, France, urged the United Nations Educational, Scientific and Cultural Organization to support a programme that would collect extra ice cores and store them at the Concordia Research Station in central Antarctica. He advocates a "one core for science, two cores for storage" approach that would preserve samples for the future while giving current scientists some to work on.

The IRD has approved a pilot programme in which Ginot will collect three cores from Col du Dôme in the French Alps in 2016, and another three from the mountain of Illimani in Bolivia in 2017. Transporting all that ice to Antarctica will pose logistical challenges, he says, and it will make his work that much more demanding. "With this approach, we have to stay three times longer," he says, to collect three times as many samples as usual.

But persuading science-funding agencies to pay to store samples that will not be used for years could be a hard sell, says Ed Brook, a palaeoclimatologist at the Oregon State University in Corvallis and co-chair of the International Partnerships in Ice Core Sciences, which advocates for ice-core research. Most funding agencies, he says, aim to fund research that is expected to lead quickly to published results. "It's harder," says Brook, "to get funding for longer-term archiving of things." Schwikowski agrees. "I don't know how we could argue, 'We could not publish this year 
because we drilled ten ice cores."

To encourage science funders to support ice-core storage, the group is working on a report that outlines the importance of preserving records of climate history. Brook expects to have it ready for a major geosciences meeting in 2016. It is important to start the effort soon, he says, because the ice, and the information it contains, is disappearing now. "You're getting rid of the part where we actually have instrumental records to compare and calibrate with," he says. "We don't have that much time."

Still, veteran palaeoclimatologists say that the rapidly changing conditions could prove a boon to the field. Much work needs to be done to understand both the rate of change in ice melt and deposition, and how current climate processes differ from those in the past, when the atmosphere contained much lower concentrations of carbon.

Younger scientists are uncertain how the changes will affect their work. "It definitely makes it harder," says Aron Buffen, a palaeoclimatology doctoral student at Brown University in Providence, Rhode Island, who has worked with Thompson on Quelccaya. If all the ice that formed in years when instruments were measuring weather data disappears, scientists will lose a point of comparison for validating future measurement techniques, he says. A dearth of ice might also discourage custodians of the few remaining samples from sacrificing them to test unproven techniques.

Still, Buffen says that the melting will lead to more questions for research. These include determining which chemical traces will remain behind in sediment and which will return to the atmosphere when the ice melts, as well as distinguishing between melting caused by warmer conditions and sublimation caused by lower humidity. "I wouldn't dissuade anyone from working on tropical glaciers," Buffen says. Future researchers, for instance, could help society to adapt to the changes taking place, if they can provide clues to how shrinking glaciers might affect local ecosystems. And ice at the world's highest spots, as well as in Antarctica and Greenland, will endure for many years to come. Thompson, too, is optimistic about the future, so much so that he offers an online palaeoclimatology course through the Chinese Academy of Sciences. Already, 26 students have enrolled and Thompson hopes that they will go on to study glaciers in the Himalayas.

"It's a bit of a gloomy situation to see these beautiful glaciers going away," says Hardy. "But from the standpoint of careers and science, it presents some interesting opportunities." -

Neil Savage is a freelance writer in Lowell, Massachusetts.

\section{TURNING POINT Arun Shukla}

Structural biologist Arun Shukla left his native India for graduate training, as have many other researchers. Unlike most, he worked with three Nobel laureates on two distant continents before returning home. Shukla describes why now is a good time to repatriate to India.

\section{How did you meet your PhD adviser?}

While I was in a master's programme in biotechnology at Jawaharlal Nehru University in New Delhi, I was learning about G-protein-coupled receptors (GPCRs), which are involved in almost every physiological process and make up the largest class of potential drug targets. I knew that I wanted to pursue research in this area and attended a fascinating talk by Hartmut Michel, a biochemist at the Max Planck Institute of Biophysics in Frankfurt, Germany, who won the chemistry Nobel in 1988. I spoke with him afterwards and sent him my CV, and he offered me a $\mathrm{PhD}$ position.

\section{What was it like at the Max Planck Institute?} It was fun. I was working on expressing GPCRs in different cell types. The goal was to crystallize enough protein to use X-ray diffraction to determine the atomic-level structure, so that we could learn how different drugs bind to these receptors. I realized that this was an area that I could work on for the rest of my life.

\section{Did your PhD work make a mark on the field?} I think so. Crystallizing GPCRs was thought to be impossible at the time. GPCRs are highly mobile proteins that sit in the cell membrane, but for crystallography to be successful you need a stable protein. As a result, their structures were not known. Using nuclear magnetic resonance spectroscopy, we were able to determine the structure of a ligand, a hormone bound to a GPCR. Understanding how a ligand bound to a receptor was a big deal, and the work was published in 2008 as a cover article in Angewandte Chemie (J. J. Lopez et al. Angew. Chem. Int. Edn Engl. 47, 1668-1671; 2008). Even today, there are only two such studies in the field. I knew that gaining any insights into GPCR structure would be a landmark and mean a lot to my career.

\section{How did you connect with your next Nobel-} laureate mentor?

I was finishing my $\mathrm{PhD}$ and knew that I wanted to continue working on GPCRs. Robert Lefkowitz, a biochemist at Duke University in Durham, North Carolina, and future winner of the 2012 chemistry Nobel, is the godfather of GPCRs. I sent him my CV and asked if I could join his lab. Without a formal interview,

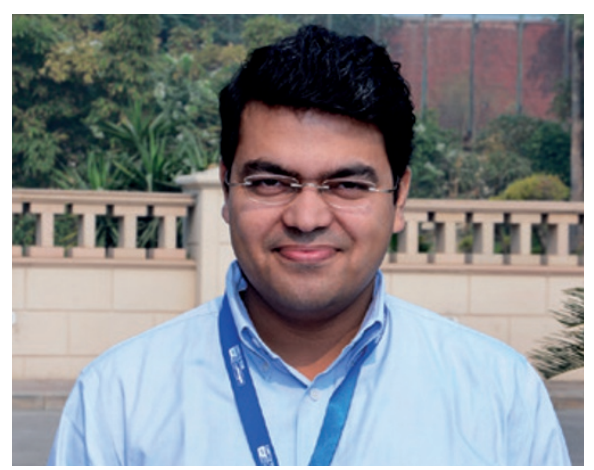

he wrote back that I was welcome.

Describe your work in such a competitive field. The goal - to gain insights into GPCR signalling - was pioneering, and there was a risk of getting scooped. In 2013, Lefkowitz, his Nobel co-recipient Brian Kobilka, and I published the structure of $\beta$-arrestin, a GPCR-regulating protein (A. K. Shukla et al. Nature 497, 137-141; 2013). Our paper was in the same issue as one from a group that crystallized a different arrestin.

\section{What prompted you to return to India?}

I had watched infrastructure and funding prospects improve in the past decade and thought I could run a better group here given the tight US funding situation, so I started applying for positions. I had several offers, and accepted one at the Indian Institute of Technology in Kanpur.

\section{How is it going?}

I have the academic freedom to establish GPCR crystallography as a new line of research in this country, with funding from the Indian Department of Science and Technology and a five-year grant from the Wellcome Trust/ Department of Biotechnology India Alliance.

\section{Have there been any roadblocks?}

It can take weeks to get reagents and consumables from the United States or Europe. We also lose our top $\mathrm{PhD}$ graduates overseas so it can be hard to find a good postdoc. My hope is that if we do good work in India, students will realize that they can stay and have high-impact papers.

What was the best piece of advice you received from the Nobel laureates?

Focus on big questions - do things that are cutting edge and will help to shape the direction of the field. We have to make discoveries, not just publish papers. 